\title{
Communication
}

[Comunicação]

\section{An atypical clinical presentation for the first isolation of Canid herpesvirus 1 in Argentina}

[Uma apresentação clínica atípica para o primeiro isolamento do herpesvirus canino 1 na Argentina]

\author{
V.E. De Palma ${ }^{1}$, M.A. Ayala ${ }^{1}$, C. Gobello ${ }^{1,2}$, M.G. Echeverria ${ }^{1,2}$, C.M. Galosi ${ }^{1,3 *}$ \\ ${ }^{1}$ Facultad de Ciencias Veterinarias - UNLP \\ 60 y 118 , CP 1900 \\ CC296 - La Plata, Buenos Aires, Argentina \\ ${ }^{2}$ Consejo Nacional de Investigaciones Científicas y Técnicas - Buenos Aires, Argentina \\ ${ }^{3}$ Comisión de Investigaciones Científicas de la Provincia de Bs As - La Plata, Buenos Aires, Argentina
}

\begin{abstract}
Canid herpesvirus 1 (CaHV-1) is a Varicellovirus of the subfamily Alphaherpesvirinae, family Herpesviridae, and order Herpesvirales, with a host range restricted to domestic and wild canids (Remond et al., 1996). CaHV-1 was first recognized as the agent responsible for causing a highly fatal hemorrhagic viral disease in newborn puppies in 1965. Apart from being an important disease in newborn puppies, CaHV-1 also affects reproduction of dogs in other ways: the virus may cause vesicular lesions in the vestibulum and vagina of the bitch, as well as on the penis and the preputial mucosa of dogs and may cause embryonic resorption, abortion, and fetal death (Carmichael, 1970). In addition, the virus is associated with respiratory (kennel cough syndrome) and ocular disease in dogs (Erles and Brownlie, 2005; Ledbetter et al., 2009). Oronasal and venereal transmission are the common routes of infection but transplacental infection has also been described. Lesions in the vestibulum and vagina of bitches may recur when bitches come into pro-estrus and regress when they go into anestrus (Carmichael, 1970; Hashimoto et al., 1982). Affected animals may remain latent carriers and the virus was identified in the lumbosacral ganglia, tonsils, parotid salivary glands, and liver of dogs that showed no sign of herpesvirus infection (Burr et al., 1996). Several studies suggest that CaHV-1 is enzootic in the
\end{abstract}

dog population. The disease was reported in numerous countries and the prevalence of antibodies (Abs) against CaHV-1 varies from 6\% in some countries to higher than $90 \%$ in other (Ronsse et al., 2005; Nöthling et al., 2008).

A first preliminary serological study performed in Argentina by a previously standardized enzyme linked immunosorbent analysis (ELISA) indicated a $23 \%$ of Abs prevalence (De Palma et al., 2006) In addition, typical clinical signs and neonatal mortality, suggesting viral activity, have been observed by Argentine breeders. This study reports an atypical clinical manifestation for CaHV-1 and the first viral isolation of this virus in Argentina.

A four-year-old privately owned female Labrador Retriever, which had been mastectomized two weeks before, presented vesicular lesions preceded by erythema in the internal part of the right thigh (Figure 1). Vesicles were surrounded by suppurative crusts and regional lymphoid nodes were enlarged. The lesions were first treated with local gentamicine (Kualcoderm, Kualcos - Buenos Aires, Argentina) for two days without improvement. Vesicular fluid was aspirated by a sterile syringe and transported in a refrigerated box to the laboratory of virology. In addition, blood samples for antibodies (Abs) detection were also

Recebido em 16 de fevereiro de 2010

Aceito em 28 de setembro de 2010

*Autor para correspondência (corresponding author)

E-mail: cmgalosi@fcv.unlp.edu.ar 
drawn. Then, the lesions were treated with $5 \%$ acyclovir (ACV - Aciclovir Lafedar - Entre Rios, Argentina) cream three times daily for five days. A first rapid diagnosis was done by polymerase chain reaction (PCR) using specific oligonucleotide primers derived from the glycoprotein B gene of CaHV-1 (P1: 5' CAG GAC TAT TGG ACT ATA GT 3', P2: 5' TTG CAA TGC CCC TCA TAA TT 3') (Burr et al., 1996). The reaction was performed from a portion of boiled vesicular fluid and the DNA of the YP-11 Japanese strain (Dr. T. Mikami Tokyo, Japan) was used as positive control. The conditions for PCR amplification were: a) 35 cycles of $94^{\circ} \mathrm{C}$ for $30 \mathrm{~s}, 57.5^{\circ} \mathrm{C}$ for $1 \mathrm{~min}, 72^{\circ} \mathrm{C}$ for $1 \mathrm{~min}$; b) final extension at $72^{\circ} \mathrm{C}$ for $5 \mathrm{~min}$. The PCR products were examined on $3 \%$ agarose gel in TBE buffer (50mM Tris pH 8.0, $50 \mathrm{mM}$ boric acid, and $1 \mathrm{mM}$ EDTA). The gels were examined under UV light following ethidium bromide staining. The molecular sizes of fragments were compared with those of a 100bp (base pairs) ladder (Promega Lab Madison, USA). A visible band of weight equal to $120 \mathrm{bp}$ was considered a positive result. As a second step, the sample was diluted 1:10 in phosphate-buffered saline (PBS), centrifuged (3000g for $15 \mathrm{~min}$ at $4^{\circ} \mathrm{C}$ ) and inoculated over confluent monolayers cultures of Madin-Darby Canine Kidney (MDCK) cells grown in twentyfour-well plates. Plates were incubated at $35^{\circ} \mathrm{C}$ in an atmosphere of $5 \% \mathrm{CO}_{2}$ and examined daily for the appearance of viral cytopathic effects (CPE). When CPE was extensive, the supernatant was separated by low speed centrifugation $\left(3000 \mathrm{~g}\right.$ for $15 \mathrm{~min}$ at $4^{\circ} \mathrm{C}$ ) and titrated in MDCK cells using the Reed and Muench method. The titer was expressed at $96 \mathrm{~h}$ post infection (pi) as $\mathrm{CCID}_{50}$ (cell culture infectious dose $50 \%) / 50 \mu \mathrm{L}$. In addition, infected and non-infected MDCK cells grown on coverslips were fixed for $30 \mathrm{~min}$ in cold acetone for routine immunofluorescence analysis (IFA). To confirm the isolates as CaHV-1, serial twofold dilutions of dog anti-CaHV-1 reference serum were mixed with $100 \mathrm{CCID}_{50}$ of the viruses isolated and after $60 \mathrm{~min}$ of incubation in a $5 \% \mathrm{CO}_{2}$ atmosphere, $100 \mu \mathrm{L}$ of MDCK cells $\left(3 \times 10^{5} \mathrm{cells} / \mathrm{mL}\right)$ were added. For standard IFA, CaHV-1 monoclonal antibodies and anti mouse conjugated to fluorescein isothiocyanate (Zymed Laboratories - San Francisco, USA) were used as primary and secondary Abs, respectively. The Abs were determined by previously conventional standardized indirect ELISA test, using a soluble antigen produced with CaHV-1 YP-11 strain infected MDCK cells (De Palma et al., 2006).

The DNA was specifically amplified by PCR, generating a product that yielded a sharp visible band of $120 \mathrm{bp}$ on an ethidium bromide gel. Identical bands were obtained from positive controls. A focus of CPE consisting of spherical cells and lysis was detected on day 3 pi and then increased after successive passages (Figure 2). The IFA showed specific nuclear fluorescence (Figure 3). The isolated virus named LPJ $\left(10^{4.5} \mathrm{CCID}_{50 \%} / 50 \mu \mathrm{L}\right)$ was confirmed as CaHV-1 by the VN test. The ELISA test was also positive and indicated that a CaHV-1 infection was produced.

$\mathrm{ACV}$ is an antiviral agent with activity against a variety of viruses that has been found to be efficacious in the management of human herpes labialis in several formulations and routes of administration. In addition, ACV has been shown to have an effect on veterinary herpesvirus (Asano, 1995; Garre et al., 2007). In the case reported in this work, it was observed that the lesions decreased rapidly from day 2 of ACV treatment. The exact explanation of this unusual CaHV-1 clinical presentation is not known. In this particular case, no other previous clinical signs were observed. As in other alphaherpesviruses, the CaHV-1 latency in sensory ganglia has been reported (Miyoshi et al., 1999). It is also known that latent viruses in the lumbosacral nodes have an important role in venereal infections (Burr et al., 1996). A possible explanation is that the virus had replicated in the epithelial cells of the vagina (self-limited primary infection), established latency, and then was reactivated by the post surgical immune depression, producing the skin lesions described. The PCR, VI, and IFA confirmed that the lesions were produced by CaHV-1.

To the authors' knowledge, the occurrence of vesicular lesions produced by $\mathrm{CaHV}$ in the area described was never reported. This is not only the first report of an atypical localization for to consider in the future, but also the first isolation of this virus in Argentina.

Keywords: dog, Canid herpesvirus 1, atypical clinical lesions, viral isolation 


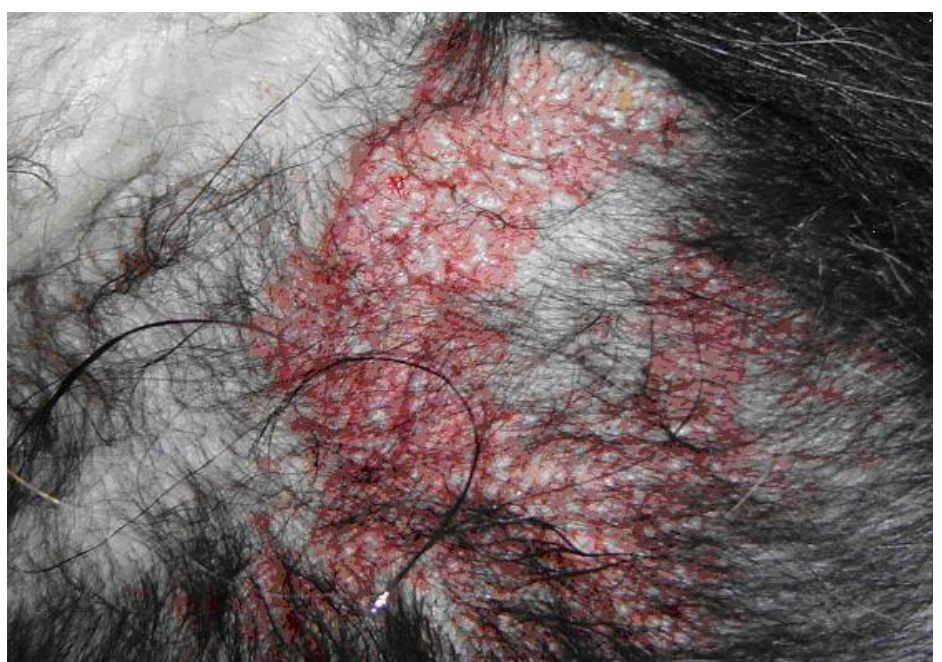

Figure 1. Skin lesions of a four-year-old female Labrador Retriever. Image shows vesicles surrounded by erythema.

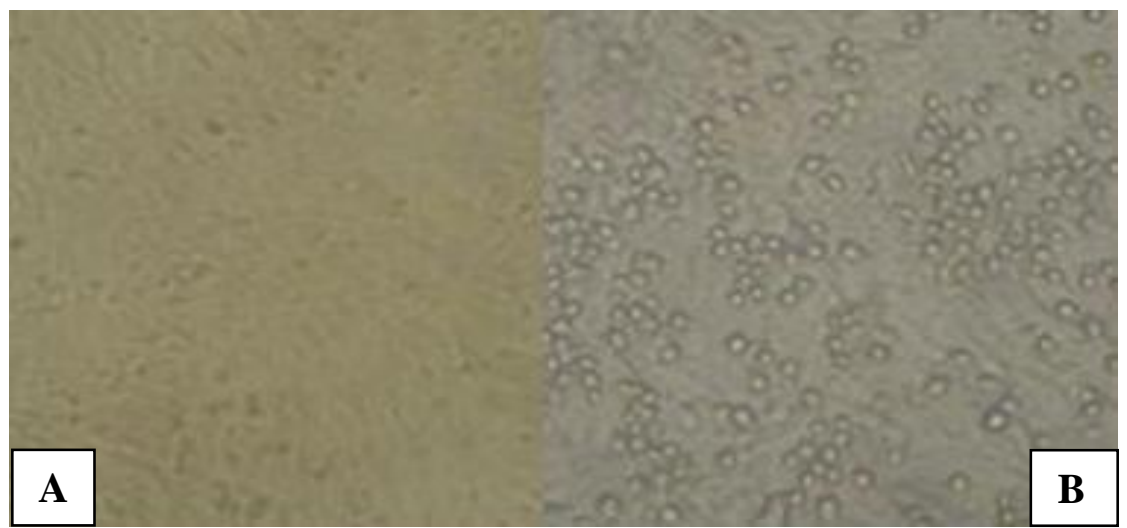

Figure 2. MDCK control cells (A) and cytophatic changes (B) observed at 3 days post infection over MDCK cells inoculated with liquid of skin lesions of a four-year-old female Labrador Retriever. (Obj. $10 \mathrm{X}$ and 20X, respectively).

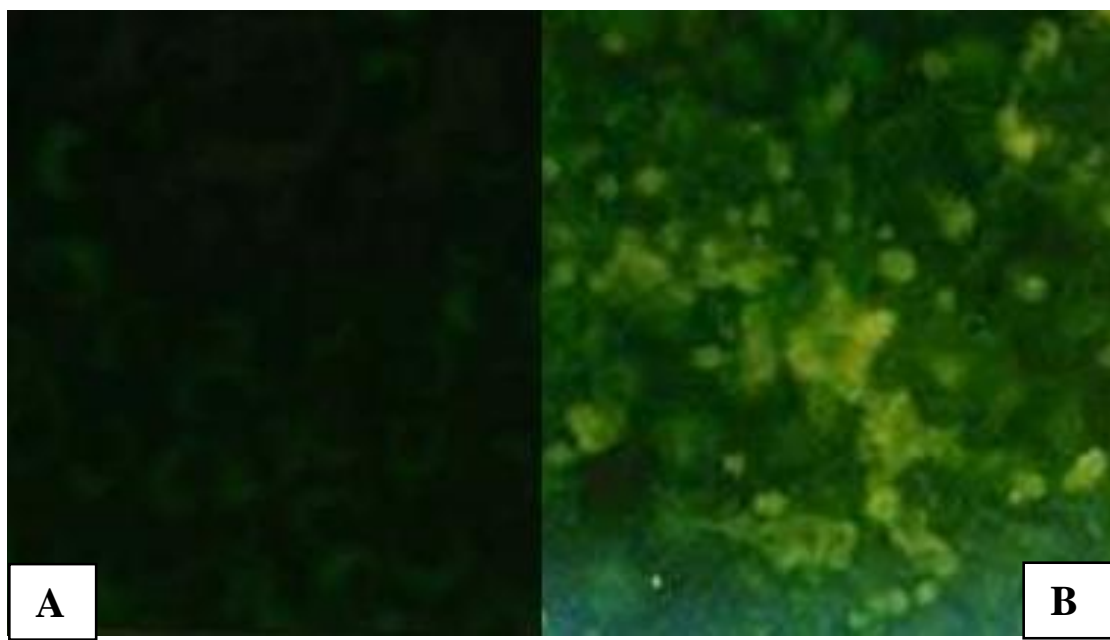

Figure 3. Immunofluorescence analysis over MDCK cells inoculated with the isolated virus. Images show negative controls cells (A) and specific positive nuclear fluorescence (B) (Obj. 25X). 


\section{RESUMO}

Relatam-se o primeiro isolamento de herpesvirus canino 1 (CaHV-1) e a localização atípica das lesões vesiculares associadas a este vírus na Argentina. A amostra foi recuperada de lesões vesiculares, localizadas na parte interna da coxa direita, em uma fêmea de raça Labrador. A cadela tinha quatro anos de idade e era de propriedade privada. O primeiro diagnóstico foi realizado pela reação em cadeia da polimerase e, posteriormente, o vírus foi isolado e sua identificação confirmada por imunofluorescência indireta e pelo teste de neutralização viral.

Palavras-chave: cão, herpesvirus canino 1, apresentação clínica atípica, isolamento viral

\section{ACKNOWLEDGEMENTS}

This study was supported by grants from the Departamento de Ciencia y Tecnologia at the Universidad Nacional de La Plata and the Scientific Research Commission, Buenos Aires, Argentina. The authors thank Dr T. Mikami (Tokyo University, Japan) for providing the YP11 reference virus strain and reference polyclonal and monoclonal antibodies against $\mathrm{CaHV}-1$.

\section{REFERENCES}

ASANO, M. An experimental trial of the prevention of canine herpesvius infection in puppies by injection of immune serum and acyclovir. Jpn. J. Vet. Res., v.43, p.68, 1995.

BURR, P.D.; CAMPBELL, M.E.M.; NICOLSON, L. et al. Detection of canine herpesvirus 1 in a wide range of tissues using the polymerase chain reaction. Vet. Microbiol., v.53, p.227-237, 1996.

CARMICHAEL, L.E. Herpesvirus canis: aspects of pathogenesis and immune response. J. Am. Vet. Med. Assoc., v.156, p.1714-1725, 1970.

DE PALMA, V.E.; ECHEVERRÍA, M.G.; GALOSI, C.M. Prevalence of antibodies against canine herpesvirus 1 in dogs of Buenos Aires Province. In: PROCEEDINGS OF THE MEETING OF ARGENTINE ASSOCIATION OF VETERINARY LABORATORY DIAGNOSTICIANS (AAVLD), 16., 2006, Mar del Plata. Proceedings... Mar del Plata, Argentina, 2006. (Abstract).

ERLES, K.; BROWNLIE, J. Investigation into the causes of canine infectious respiratory disease: antibody responses to canine respiratory coronavirus and canine herpesvirus in two kennelled dog populations. Arch. Virol., v.150, p.1493-1504, 2005.
GARRÉ, B.; VAN DER MEULEN, K.; NUGENT, J. et.al. In vitro susceptibility of six isolates of equine herpesvirus 1 to acyclovir, ganciclovir, cidofovir, adefovir, PMEDAP and foscarnet. Vet. Microbiol., v.122, p.43-51, 2007.

HASHIMOTO, A.; HIRAI, K.; YAMAGUCHI, L. et al. Experimental transplacental infection of pregnant dogs with canine herpesvirus. Am. J. Vet. Res., v.43, p.844-850, 1982.

LEDBETTER, E.C.; KIM, S.G.; DUBOVIT, E.J. Outbreak of ocular disease associated with naturally-acquired caine herpesvirus- 1 infection in a closed domestic dog colony. Vet. Ophthalmol., v.12, p.242-247, 2009.

MIYOSHI, M.; ISHII, Y.; TAKIGUCHI, M. et al. Detection of canine herpesvirus DNA in the ganglionic neurons and the lymph node lymphocytes of latently infected dogs. J. Vet. Med. Sci., v.61, p.375-379, 1999.

NÖTHLING, J.O.; HÜSSY, D.; STECKLER. D. et al. Seroprevalence of canine herpesvirus in breeding kennels in the Gauteng Province of South Africa. Theriogenology, v.69, p.276-282, 2008.

REMOND, M.; SHELDRICK, P.; LEBRETON, F. et al. Gene organization in the UL region and inverted repeats of the canine herpesvirus genome. J. Gen. Virol., v.77, p.37-48, 1996.

RONSSE, V.; VERSTEGEN, J.; THIRY, E. et al. Canine herpesvirus-1 (CHV-1) clinical, serological and virological patterns in breeding colonies. Theriogenology, v.64, p.61-74, 2005 